HEROES AND MARTYRS OF QUALITY AND SAFETY

\title{
"Cotton Mather, you dog, dam you! I'I inoculate you with this; with a pox to you'": smallpox inoculation, Boston, 1721
}

M Best, D Neuhauser, L Slavin

Qual Saf Health Care 2004;13:82-83. doi: 10.1136/qshc.2003.008797

$\mathrm{T}$ he semi-literate quotation in the title comes from a note attached to a bomb thrown into Cotton Mather's house in Boston, Massachusetts on 14 November 1721 because of Mather's public advocacy of the most important healthcare improvement of the colonial American erasmallpox inoculation.

\section{SMALLPOX}

Smallpox has a long history, with descriptions as early as 1350 BC in Egypt. Epidemiologists believe it originated in north eastern Africa about $10000 \mathrm{BC}$. The mummy of Pharaoh Rameses V of Egypt who died about 1160 BC had lesions on his face that were thought to be caused by smallpox. Europeans brought "small pox" to the New World and received, in turn, "the great pox", or syphilis. Other names for smallpox are "red death" and the "speckled monster". ${ }^{2-4}$

The disease arrived in the western hemisphere in 1507 on the Caribbean island of Hispañola and went on to devastate the natives, making European conquest of the Americas possible. Later, there are reports of colonists giving North American Indians smallpox infected cloth in an early form of bioterrorism. ${ }^{5}$ New England had periodic epidemics in the 1600 s and again in 1702. Those who survived were then immune and for 19 years there were no more smallpox epidemics in Boston.

On 22 April 1721 the HMS Seahorse, a British ship arriving from Barbados, docked in Boston harbor. Within a day of passing the customary inspection a crew member exhibited symptoms of smallpox. He was quarantined in a house near the harbor and a red flag was put up in front of the house that read "God have mercy on this house". ${ }^{6-8}$ By early May nine more crew members showed signs of acute smallpox. They also were quarantined, but soon afterwards cases were appearing in resident Bostonians.

Reverend Cotton Mather, a polymath with an interest in medicine, wrote in his diary on 26 May: "The grievous calamity of the small pox has now entered the town". Within the first few days about 1000 people left town with the hope of avoiding the disease. Cotton Mather was instrumental in introducing smallpox inoculation to the United States. He wrote regarding inoculation: "I had from a servant of my own an account of its being practised in Africa. Inquiring of my Negro-man, Onesimus, who is a pretty intelligent fellow, whether he had ever had the smallpox, he answered both yes and no. He told me that he had undergone the operation which had given something of the smallpox and would forever preserve him from it, adding that was often used in West Africa."

\section{INOCULATION}

Inoculation has been reported as early as 1000 BC in China, where it was performed by introducing smallpox material via a scratch in the skin or by putting some cotton soaked in

Give someone smallpox to prevent it? This treatment from Africa was too radical for Boston in 1721. Proving it required a breakthrough in research methodology.

variola pus into the nostril, or by blowing the dried powder from scabs into the nostrils via a tube. In India, variolation was performed by introducing variola pus or scabs into the skin of healthy people. Lady Mary Wortley Montague gets the most credit for bringing inoculation or variolation to Great Britain. She learned of the technique in Turkey while with her ambassador husband on a diplomatic mission. Inoculation uses human smallpox. The inoculated person had a milder infection than taking smallpox "in the natural way", but was infectious to others during the induced illness. William Jenner's cowpox vaccination (from the latin word vacca meaning cow) discovered in 1796 had lower mortality than inoculation and the patient was not infectious to others.

Mather gets the most credit for bringing inoculation to North America, although he should share the honor with the unknown Onesimus. Mather sent a letter to Dr Zabdiel Boylston which convinced the doctor to start a campaign of inoculation. Other physicians in the Boston area also received letters from Mather, but they did not respond to his call to battle against this "most terrible of all the ministers of death". Dr Boylston wrote on 26 June 1721: "I inoculated my son, Thomas, of about six, my Negro-Man, thirty-six, and Jackey, two and a half Years old". He inoculated others in July and on 12 August 1721 he inoculated Mather's son Samuel. In total, he inoculated 287 Bostonians and, of these, six died.

\section{VILIFICATION}

Many of the town's people were against inoculation, including members of Mather's congregation. All the physicians in town except Boylston were opposed to his crusade. They were led by the only physician in Boston with the MD degree, Dr William Douglass. John Checkley, an apothecary who had a personal feud with Mather, and Douglass formed the Society of Physicians Anti-Inoculators which met regularly in coffee houses to denounce inoculators.

The July 17-24 edition of the Boston News-Letter published an article by Dr William Douglass that attacked Boylston for performing inoculations. On 7 August James and Benjamin Franklin published additional attacks in their newspaper, the New England Courant. The ministers of Boston thought this sensational article was "freighted with Nonsense, ... Prophaneness, Immorality, ... Lyes, Contradictions" and had James put in prison for four weeks while his apprentice Benjamin Franklin continued to publish the paper on his own. Years later Benjamin Franklin became an active supporter of inoculation. 
In November 1721 a small bomb was tossed through the window of Mather's house and landed in the room where Mather's nephew was recuperating from the inoculation procedure. The fuse of the bomb burned out so the bomb did not explode and the attached note, quoted in the title of this article, was not destroyed.

Mather and Boylston reported that 2\% of 287 inoculated patients died compared with 842 deaths among the 4917 infected in the natural way $(14.9 \%){ }^{9}$ As far as we know, this is the first use of numbers to evaluate a clinical trial. Mortality from the experimental group is compared with a control group and proportional mortality measured and compared to demonstrate a clear difference. ${ }^{8}$ It was these comparative quantitative data replicated in later epidemics which led to the slow but steady acceptance of inoculation in Boston. The success of inoculation paved the way for acceptance of Jenner's vaccination. Beall et al describe Mather as "the first significant figure in American medicine." ${ }^{\prime 10}$

\section{COTTON MATHER}

Unfortunately, we know next to nothing about Onesimus, a bit about Boylston, and a lot about Cotton Mather (16631728) who comes across as the high priest of New England Puritanism. At the age of 16 he was one of the youngest graduates ever of Harvard University, father of 15 children, and a prolific writer whose bibliography alone takes up three published volumes. ${ }^{11}$ Many of his 468 publications were books rather than articles, and most are forgettable sermons. He liked to use a dozen words when one would do, and to quote in Hebrew, Greek, and Latin; in short, a vast opus of no or little appeal to our present age. However, some of these books are important. His 1702 ecclesiastical history of New England Magnalia Christi Americana is "a monument of early American literature", ${ }^{12}$ Bonifacius has a direct influence on Benjamin Franklin's life, ${ }^{13}$ and The Angel of Bethesda is "the only large inclusive medical work of the entire American colonial period". ${ }^{14}$ Filled with folk remedies, it was not published until 1972.

The curse of Cotton Mather is that he wrote one book too many and he has been condemned from the day of its publication down to the present. In Wonders of the Invisible World he sought to justify the Salem witch trials of $1672 .{ }^{15-17}$ This curse hangs over the head of all today's vastly productive academics who might write just one book too many.

\section{HERO OR MARTYR?}

Mather was both. He was the first native born American to become a member of the Royal Society of London. Inoculation was the most important health improvement of colonial America as documented by the early (and perhaps the first) use of numerical analysis to evaluate a clinical trial.

\section{Authors' affiliations}

M Best, D Neuhauser, L Slavin, Department of Epidemiology and Biostatistics, Case School of Medicine, Case Western Reserve University, Cleveland, Ohio, USA

Correspondence to: Professor D Neuhauser, Department of Epidemiology and Biostatistics, Case School of Medicine, Case Western Reserve University, Cleveland, OH 44106-4945, USA; dvn@case.edu

\section{REFERENCES}

1 Silverman K. The life and times of Cotton Mather. New York: Harper Row, 1984.

2 Aronson SM, Newman L. "God have mercy on this house: Being a brief Chronicle of Smallpox in Colonial New England". Smallpox in the Americans 1492 to 1815: contagion and controversy. John Carter Brown Library of Brown University, December, 2002.

3 Stetten Jr D. Victory over variola. ASM News 1978;44:639-44.

4 Barquet N, Domingo P. The triumph over the most terrible of the ministers of death. Ann Intern Med 1997; 127:635-42.

5 Hopkins D. Princes and peasants: smallpox in history. Chicago: University of Chicago Press, 1983.

6 Rudolph R, Musher DM. Inoculation in the Boston smallpox epidemic of 1721. Arch Intern Med 1965;115:692-6.

7 Winslow 0 . A destroying angel: the conquest of smallpox in colonial Boston. Boston: Houghton Mifflin, 1974.

8 Blake JB. Public health in the town of Boston 1630-1822. Cambridge, MA: Harvard University Press, 1959.

9 Best MA, Neuhauser D, Slavin L. Benjamin Franklin: verification and validation of the scientific process in healthcare. Victoria, BC, Canada: Trafford Publishing, 2003.

10 Beall OT, Shryock RH. Cotton Mather, first significant figure in American medicine. Baltimore: Johns Hopkins Press, 1954.

11 Holmes TJ. Cotton Mather, a bibliography of his work. Cambridge, MA: Harvard University Press, 1940.

12 Mather Cotton. Magnalia Christi Americana. Murdock K, ed. Books I and II. Cambridge, MA: Harvard University Press, 1977.

13 Mather Cotton. Bonifacius: an essay upon the good. Levin D, ed. Cambridge, MA: Harvard University Press, 1966.

14 Mather Cotton. The Angel of Bethesda. Jones G, ed. Barre, MA: American Antiquarian Society, 1972.

15 Mather Cotton. Wonders of the invisible world. Observations as well historical as theological upon the nature, the number and operations of the devil. Boston: 1692.

16 Levine D. Cotton Mather: the young life of the Lord's remembrancer, 16631703. Cambridge, MA: Harvard University Press, 1978.

17 Boyer P, Nissenbaum S. Salem possessed. The social origins of witchcraft. Cambridge, MA: Harvard University Press, 1974. 